\title{
Analyze of elements of the productive chain of fingerlings of rheophilic species: pilot study in the Amazon region
}

\author{
Natalia Bianca Caires Medeiros ${ }^{1}$, Marcela Cristina Flexa do Amaral ${ }^{2}$, Geciele Santos Cruz ${ }^{3}$, Leandro de Lima Sousa ${ }^{4}$, Igor Guerreiro Hamoy \\ and Marília Danyelle Nunes Rodrigues ${ }^{5,6 *}$ \\ ${ }^{1}$ Programa de Pós-Graduação e Produção e Saúde Animal na Amazônia, Universidade Federal Rural da Amazônia- UFRA, Belém, PA, Brasil \\ ${ }^{2}$ Zootecnista, Campus Parauapebas, Universidade Federal Rural da Amazônia- UFRA, Paruapebas, PA, Brasil \\ ${ }^{3}$ Graduanda em Zootecnia, Campus Parauapebas, Universidade Federal Rural da Amazônia- UFRA, Paruapebas, PA, Brasil \\ 4Engenheiro Agrônomo, Campus Parauapebas, Universidade Federal Rural da Amazônia- UFRA, Paruapebas, PA, Brasil \\ ${ }^{5}$ Laboratório de Genética Aplicada, Instituto Sócio-Ambiental e dos Recursos Hídricos - ISARH, Universidade Federal Rural da Amazônia - UFRA, Belém, PA, \\ Brasil \\ ${ }^{6}$ Programa de Pós-Graduação em Produção Animal na Amazônia, PA, Brasil
}

\begin{abstract}
The objective of this pilot work was to perform a study about the main elements of the productive chain of rheophilic fingerlings in the Mesorregião of Southeast of Pará, in Amazon region, raising their main characteristics of productive, installations and management. From the information obtained, questionnaires were applied to fish producers. Were identified 6 fish farms in region. Among the interviewed fish farmers, the average time (years) that work in the production of fingerlings is 10.8 years. Tambaqui, is the native fish most produced besides other round species. The total number of ponds of the region is 239 , and $44 \%$ used for raising and $56 \%$ used in the stocking of breeders (male and female). All producers interviewed monitor water quality, the majority (33\%) comes from dams. And regarding sanitary issues, $67 \%$ say they do not have problems with diseases in animals. The total number of fish that make up the reproductive is 3,740 animals. We conclude with this pilot study that the fingerlings production units are lacking in technical information, fundamental factor for a change in the system by means of management and planning, ensuring sustainability for the development of fish farming in the region.
\end{abstract}

\section{Introduction}

Round species are considered to be more commercially produced in the Brazilian Amazon. Due to its high acceptability by the consumers, it has an interest aroused by fish farmers from different regions. As food demand increases as a result of population growth and the depletion of natural stocks, food production in the field is becoming increasingly difficult, especially with regard to management and future decisions [1].

However, some variables compromise the success of a rural enterprise, such as management, technical knowledge and planning. In the national fish culture, the strategic planning and management studies are incipient and restricted, mainly in the area of fish reproduction and management [2].

In particular, fish farming is a lucrative activity, however, it is necessary to apply techniques already established experimentally. Specialized technical assistance is the first step in developing this activity, in which good practices will be adopted with the guarantee of a business within the technical and scientific standards and careful application of resources [3].

A positive result in the increase of productivity of the sector has been seen in the state of Rio Grande do Sul after the emergence of initiatives in partnerships with Government, Universities and institutions such as EMATER, SEBRAE, prefectures, associations and cooperatives of fish farmers [2].
Currently the State of Pará, in the Brazilian Amazon, does not have a survey or data available on the sector, as well as information on the technical assistance provided to the producers, growing conditions, number, genetic characterization and origin of the reproducers about the main fish species produced in the state.

Nevertheless, in the state of Pará and especially in the Carajás region of Southeast of Pará, there is little information and data available on fish production, requiring a survey of data mainly on the current conditions of fish producers, as well as information on laboratories production of fingerlings among other information, which are necessary for the planning and management of the production chain as a whole.

The objective of this work is a pilot study, about the main elements of the productive chain of rheophilic fingerlings in the Mesorregião of Southeast of Para, in Amazon region, raising their main characteristics of productive, installations and management.

${ }^{\star}$ Correspondence to: Marília Danyelle Nunes Rodrigues, Programa de PósGraduação em Produção Animal na Amazônia, Laboratório de Genética Aplicada, Instituto Sócio-Ambiental e dos Recursos Hídricos - ISARH, Universidade Federal Rural da Amazônia - UFRA, Belém, PA, Brasil, Tel: +55 91 984068863; E-mail: nunes.mdnunes@gmail.com;danyelle.rodrigues@ufra.edu.br

Key words: fish, aquaculture, sustainability, development in the Amazon Received: April 05, 2021; Accepted: April 30, 2021; Published: May 07, 2021 


\section{Material and methods}

In order to systematize the data collection, information about the producers was sought from in public agencies such as SEBRAE, EMATER, prefectures and associations or cooperatives of fish farmers in the state of Pará.

From the information obtained, questionnaires were applied to fish producers, this questionnaire was adapted to the proposed by Guerreiro et al. [2] which contained questions regarding the enterprise, technical assistance provided, fishponds on the property, water used in the enterprise, sanitation of ponds water and laboratory, breeding stock, criteria for selecting breeding stock, breeding laboratory, induction, larviculture and fingerlings production.

Visits were made to the fingerlings producers of the municipalities of Marabá, Xinguara, Tucumã, Breu Branco and Parauapebas. Locations where fish producers were registered by public agencies. The Project team traveled in alternating periods to the mentioned municipalities (Figure 1).

The data were tabulated in an Excel spreadsheet and submitted to descriptive statistical analysis using BioStat $^{\odot}$ v5 software (AnalystSoft Inc.).

\section{Results and discussion}

In the survey and distribution of fingerlings production units FPU's - in Carajás region, 6 producers were identified, of which $33 \%$ were located in the municipality of Tucumã, and the remaining $67 \%$ were divided between the municipalities of Breu Branco, Parauapebas, Marabá and Xinguara. Among the interviewed fish farmers, the average time (years) that work in the production of fingerlings is 10.8 years ( \pm 7.82).
In relation to production, the region presented a total of 12,220 million fingerlings per harvest (Table 1), with the most produced species being tambaqui (Colossoma macropomum) and its hybrids, the tambatinga (Colossoma macropomum (female)) $x$ (Piaractus brachypomus (male)) and tambacu (Colossoma macropomum (female) $x$ (Piaractus mesopotamicus (male)).

Tambaqui is the native fish most produced in the country, besides other round species, such as pirapitinga, pacu and hybrids. This popularization of tambaqui by growers is attributed to the easy production of fingerlings, their rapid growth, resistance to high temperatures in nursery water, handling, diseases resistance and in addition to resisting low levels of dissolved oxygen [4-6].

It was possible to observe that the total number of ponds of the properties is 239 , and $44 \%$ (106 fishponds) of this total used for raising and 56\% (133 fishponds) used in the stocking of breeders (male and female).

This study verified that $33 \%$ of the producers, make use of water to supply the properties, and the remaining $67 \%$ are divided in water springs, stream and well. However, the waters from springs may contain high levels of iron ( $\mathrm{Fe} 3+$ ), which when in contact with oxygen precipitates in the form of iron hydroxide - $\mathrm{Fe}(\mathrm{OH}) 3$, which can cover up the chorion preventing gas exchange of the embryo [7]. Thus, it is recommended that water with this characteristic are subjected to a resting tank, for separating the iron hydroxide before being used for the supply of incubators [2].

All producers interviewed monitor water quality, with $\mathrm{pH}$ being the most analyzed parameter $(83.3 \%)$. Moreover, although the other parameters (temperature, alkalinity, dissolved oxygen, ammonia and nitrite) are of great relevance, few producers do so. However, the

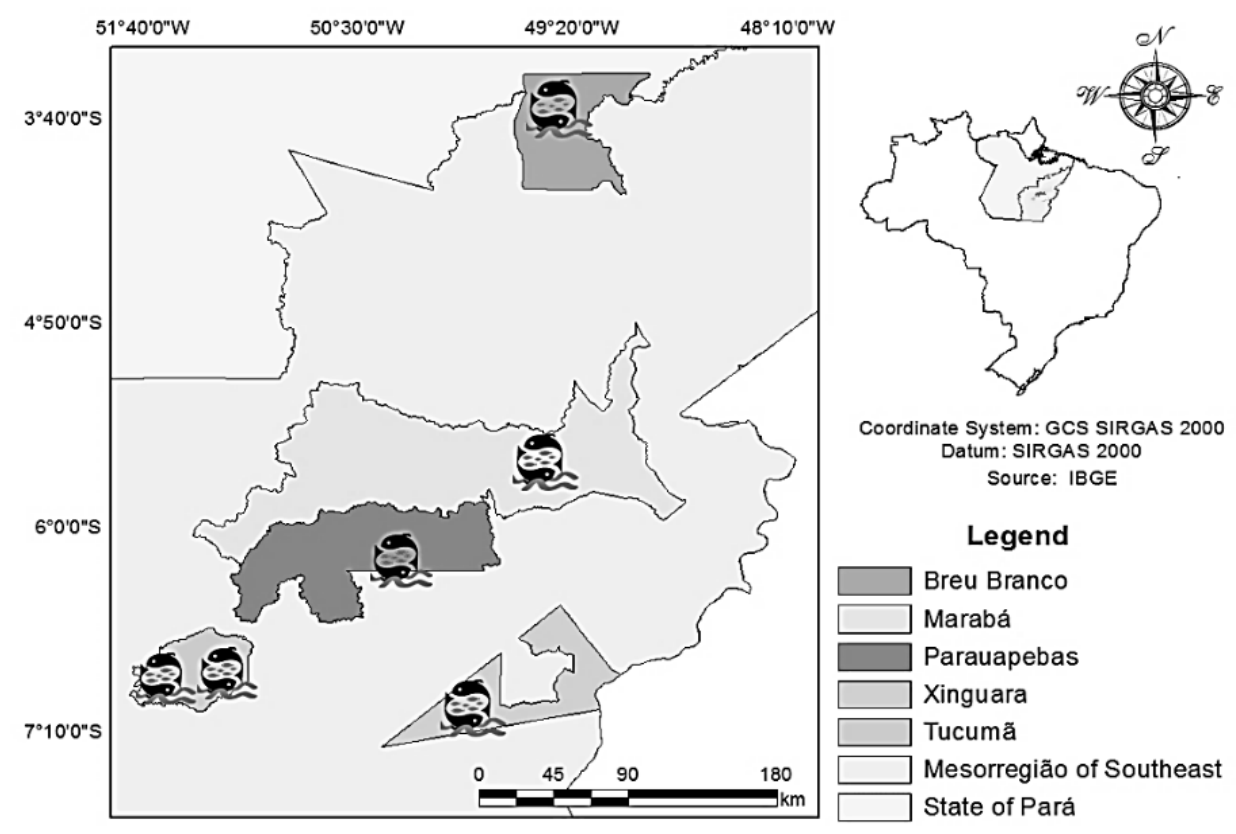

Figure 1. Map of the location of the municipalities producing fingerlings, crop session 2015-2016. 
Table 1. Species and quantities produced in fingerlings production units Mesorregião Southeast of Pará, Brazil

\begin{tabular}{|l|c|c|}
\hline \multicolumn{1}{|c|}{ Species produced } & Scientific name & Quantity (mi) \\
\hline Curimatã & Prochilodus lineatus & 0,020 \\
\hline Pacu Caranha & Piaractus mesopotamicus & 0,017 \\
\hline Piau & Leporinus freiderici & 0,012 \\
\hline Pirarucu & Arapaima gigas & 0,0101 \\
\hline Tambacu & Colossoma macropomum x Piaractus mesopotamicus & 0,0150 \\
\hline Tambatinga & Colossoma macropomum x Piaractus brachypomus & \\
\hline Tambaqui & Colossoma macropomum & \\
\hline Outras espécies & - & 0,0150 \\
\hline Total & - & 2,25 \\
\hline Source: Research data & & $12,220.000$ \\
\hline
\end{tabular}

Table 2. Information related to animal feeding management

\begin{tabular}{|c|c|c|c|c|c|c|}
\hline $\begin{array}{l}\text { Stocking density } \\
\qquad\left(\mathrm{m}^{2-1)}\right.\end{array}$ & Feeding & $\begin{array}{c}\text { Rationing } \\
(\% \text { L.W) }\end{array}$ & $\begin{array}{l}\text { PB } \\
(\%)\end{array}$ & $\begin{array}{c}\text { Granulometry } \\
(\mathbf{m m})\end{array}$ & Ration (R\$) & Phyto-Zooplankton (R\$) \\
\hline 300 & Phyto-Zooplankton & 8 & $45-50$ & $0.5-2.5$ & $7.750,00$ & $3.587,66$ \\
\hline
\end{tabular}

accuracy of the water quality results will be more reliable, depending on the quality of the monitoring and so it is possible to presume under what conditions the animals are exposed [8].

Regarding sanitary issues, $67 \%$ (4 producers) say they do not have problems with diseases in animals. It can be inferred that the little, almost minimal incidence of diseases in the animals is due to the fact that the water of origin is of good quality.

The total number of animals that make up the reproductive and parent stock of the fingerlings production units is 3,740 animals. However, no producer performs controlled genetic improvement or monitoring with microchip. The information of the breeding stock together with the tabulation of the data guarantees to the fish farmers the identification of potential matrices, in addition to the age at which the reproductive senescence begins and the weight in $(\mathrm{kg})$, such information is decisive for the discarding of breeding animals [9].

In addition to genetic improvement, the control of the reproductive biomass is an important point in the development, especially in the monitoring of the alimentary management and the individualized monitoring of the reproducers (it can be through microchips), that starts from the entrance in the establishment, giving segment to the productive indexes number of spawns, ovum egg production, seminal quality, fertilization rates, larval hatching and survival, and the quality of the fry produced [2].

The reproduction laboratories, they have an average of $114 \mathrm{~m}^{2}$, using at least 4 tanks of induction and 10 incubators, with a capacity ranging from 500 to 5,000 L/incubator, using 200 eggs/ incubator, with an average stay of 6.8 days, being fed at this stage in $60 \%$ of the properties. Regarding the number of incubators, a total of 57 units, used for eggs and larvae (mean of 9.5 incubators / FPU's).

As for the equipment that compose the laboratories, it was verified that only $29 \%$ have a magnifying glass and / or microscope, used for the correct monitoring of fertilization and hatching rates. The monitoring of fertilization and hatching rates are fundamental, since the quantification of post-larvae produced spawning, allows estimation of stocking densities in fishponds, consequently determining the number of ponds required for fish culture, in addition to the amount of feed $(\mathrm{kg}$ / day) that will be applied in the post-larva stage [10].

During the larval phase, the mean stocking density was 300 larvae $\mathrm{m}^{2}$, initially fed by environment enriched with phytoplankton, and posteriorly with average feed of $8 \%$ of live weight, with crude protein between 45 and $50 \%$, an initial particle size of $0.5 \mathrm{~mm}$, extending up to $2.5 \mathrm{~mm}$, costing farmers an average of $\mathrm{R} \$ 6,750.00$.

Besides that, natural food sources such as phytoplankton and fertilization costing an average of R \$3,587.66 (Table 2). Yet, according to Pereira et al. [11], larviculture is one of the most critical phases of fish development, and its success is associated with food management, which is capable of providing higher rates of survival and growth.

As for the production flow, $60 \%$ of the producers claim to market locally, the remainder delivers in the region, and in the states of Tocantins, Goiás and Minas Gerais. The fingerlings are marketed with an average of $3 \mathrm{~g}$, with about $3 \mathrm{~cm}$.

Among the interviewed producers, $100 \%$ said they are satisfied with fish farming in the state and intend to expand the enterprise for the coming years.

Regarding the difficulties faced, the lack of knowledge, absence of technical assistance, problems with water quality and acquisition of ration are among the main points pointed out in the research. Small producers are more susceptible to the bottlenecks present in the production chain of fish farming, encompassing several links, ranging from inputs, production and even marketing. Therefore, the understanding and knowledge of the same could in the near future conquer their position, besides making it sustainable in the system [11].

\section{Conclusion}

The data presented demonstrated the relevance of this research, reporting it was verified that the fingerlings production units are lacking in technical information, fundamental factor for a change in the system by means of management and planning, ensuring sustainability for the development of fish farming in the region.

\section{References}

1. Oliveira D de PR (2006) Strategic planning: Concepts, methodology and practices. São Paulo: Atlas: 303.

2. Guerreiro LRJ, Rodrigues MDN, Moreira HLM, Streit JR DP (2015) Characterization of unit producing fingerlings of Rio Grande of South, Brazil. Intern J Develop Res 5: $4720-4724$.

3. Sepaq (2017) Secretariat for fisheries and aquaculture.

4. Araújo-lima CARM, GOMES Lde C Tambaqui (2005) Native species for fish farming in Brazil. Santa Maria: Ed. da Federal University of Santa Maria. Ed. da UFSM: 175202 . 
5. Port MSA (2005) Stress indicators in Amazonian regions: Sensitivity to the type of stressor. $38 \mathrm{f}$. Master's thesis - National Amazon Research Institute, Federal University of Amazonas, Manaus.

6. Fgde P (2009) Performance of tambaqui (Colossoma macropomum), pirapitinga (Piaractus brachypomum), and the tambatinga hybrid (C. macropomum x P. brachypomum) kept in fertilized nurseries, in the fattening phase $-57 \mathrm{f}$. Master's thesis - Federal University of Goiás, Veterinary School.

7. Kubitza F (2004) Reproduction, larviculture and production of fingerlings of native fish. Jundiaí: Aqua Supre: 82. (Advanced fish collection).

8. Wambach XF (2009) Practical management applied to freshwater fish farming. 2012 $28 \mathrm{f}$. Master's thesis - Federal Rural University of Pernambuco, Fishery Resources and Aquaculture.
9. Guerreiro LRJ, Streit Jr DP, Rotta MA (2014) Management in the reophilic fish fry production unit: Production costs and good management practices. Online Costs and Agribusiness, Porto Alegre 10: 3.

10. Guerreiro LRJ, Rodrigues MDN, Moreira HLM, Streit JR DP (2015) Characterization of unit producing fingerlings of Rio Grande of South, Brazil. Inter J Develop Res 5: $4720-4724$.

11. Filho MXP, Barroso RM, Flores RMV (2014) Diagnosis of the fish production chain in the State of Tocantins. Research and development bulletin, Embrapa Pesca e Aquicultura.

Copyright: $@ 2021$ Medeiros NBC. This is an open-access article distributed under the terms of the Creative Commons Attribution License, which permits unrestricted use, distribution, and reproduction in any medium, provided the original author and source are credited. 